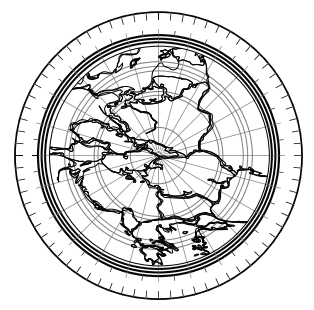

Sprawy Narodowościowe: Seria nowa, 2021(53), Article 2482

\title{
How Poles Radicalised Belarusians: On the Mechanism of Coercion
}

DOI: https://doi.org/10.11649/sn.2482

\author{
Katarzyna Kurza \\ University of Biatystok \\ https://orcid.org/0000-0002-4521-5326 \\ e-mail: k_kurza@op.pl
}

\begin{abstract}
The great reconstruction of Central-Eastern Europe after World War I mainly consisted in building national states in place of multinational empires, but it also involved social transformations. The changes carried out in highly ethnically diverse and socially polarised area of the former Polish-Lithuanian Commonwealth were selective and contributed to the contentious actions of the indigenous people. Their radicalism was often a response to a new order, created as an attempt to reproduce the feudal system in the realities of the national state. In this article I show the path of radicalisation in repressive settings, which Belarusians followed in an unequal struggle for their rights. I attempt to explain their radicalism by geocultural factors, which I regard as causal mechanisms, repeated in different historical contexts. I identify two such mechanisms, of coercion and of blocking change, and present how radicalism was generated by the operation of this binary sequence.
\end{abstract}

Keywords: Belarusians; the Second Polish Republic; radicalisation; coercion; repressions

The study was conducted at the author's own expense.

No competing interests have been declared.

Publisher: Institute of Slavic Studies, Polish Academy of Sciences.

This is an Open Access article distributed under the terms of the Creative Commons Attribution 3.0 PL License (creativecommons.org/licenses/by/3.0/pl/), which permits redistribution, commercial and non-commercial, provided that the article is properly cited. (c) The Author 2021. 
I mieli chyba rację chłopi po wsiach, którzy mówili: „Nieważne jest, kto będzie rządził. Ważne jest, czy da żyć, czy nie da żyć."1

(Mackiewicz, 1994, p. 40)

\section{Introduction}

In January 1927, one of the main topics of discussion in Polish public opinion was the mass perquisitions and arrests of the activists of the Hromada (Białoruska Włościańsko-Robotnicza Hromada, Belarusian Peasants' and Workers' Union Hromada). The Polish press was describing the movement with 100,000 members as part of a communist conspiracy aimed at destroying the Polish state, and the leaders were presented as paid agents of the Komintern. The organisation operated legally and managed to unite almost all Belarusian political groups (cf. Fedorowycz, 2020), as well as to mobilise peasants, something that had been unattainable before. Despite making radical demands, Hromada used peaceful methods.

Hromada might be acknowledged as the last relatively serious Belarussian attempt to achieve political agency in the interwar period. The attempt failed, like other earlier actions. Considering the reasons for the failure of the Belarusian national movement, previous research points out mainly its weakness, internal structure, and the external geopolitical situation. This article aims at reconstructing the trajectory of radicalisation of the Belarusians, the trajectory that led to the rise and collapse of Hromada, and at highlighting the role of geocultural factors in the formation of radicalism. Such an approach helps to explain why members of the then politically inactive traditional community were becoming radicals.

Looking at relations between radicalism and geocultural conditions is justified for several reasons. One of them is the role these factors play in defining radicalism. Radicalism is a contextual concept that has no meaning on its own (Sedgwick, 2010). Whether someone or something is defined as radical "depends on an itself problematic notion of what is 'normal', 'moderate', or 'mainstream' as a point of reference" (Malthaner, 2017, p. 371) and on its position in regard to dominant ideas (Tormey, 2008, p. 48).

Firstly, radicalism concerning the cognitive sphere does not denote "a particular set of ideas or arguments, but rather any ideology or position that takes issue (or appears to take issue) with settled, accepted or otherwise mainstream views" (Tormey, 2008, p. 48). Therefore, the different meanings of radicalism are produced by the variability of historical and political contexts, including geocultural one. Secondly, the research on terrorism sees "root causes" leading to radicalisation in cultural habits. Furthermore, geocultural factors

1 And the peasants in the villages were probably right when they were saying: "It doesn't matter who will be in power. It's important whether they will let us live or not". 
are taken into account in studies on nationalism. ${ }^{2}$ Dividing nationalism into Western and Eastern one has already been negated, ${ }^{3}$ but there is still a tendency to link different forms of nationalism to geocultural areas.

In this article I use the perspective of historical sociology, determined primarily by thinking of social reality as an everlasting process of change in which a human is an agent. This point of view allows me to perceive radicalism as a profound transformation of the existing social order. It indicates that radicalism can be better understood as a form of politics (Calhoun, 2012; McAdam et al., 2001) and not as disorder, social pathology, or manifestation of mental disorders. Historical sociology highlights both the winning variants of social order and those that never had the chance to come into existence. It is these denied alternatives that often manifest as radicalism. Moreover, this approach pushes us towards seeking causal regularity. Explaining a phenomenon needs "to identify its recurrent causal mechanisms, the ways they combine, in what sequences they recur, and why different combinations and sequences, starting from different initial conditions, produce varying effects on the large scale" (McAdam et al., 2001, p. 13).

In this case study, the research strategy is much more modest but employs the above logic. My first step is to extract geocultural factors potentially related to radicalism. I treat them not as static structural characteristics but as causal mechanisms, understood as "delimited sorts of events that change relations among specified sets of elements in identical or closely similar ways over a variety of situations" (McAdam et al., 2001, p. 25). This facilitates the perception of contentious activities not as isolated episodes but as a trajectory dynamised by components deeper than those resulting from the current situation. The assumption of their recurrence opens up explicative possibilities for other cases.

After discussing geocultural mechanisms, I present the socio-political context and indicate the dominant positions, referring to the perception of Belarusian attitudes as radical. I show how the coercive mechanism was changing the nature of the foregoing Polish-Belarusian interactions. First, I disaggregate it into particular actions of the Polish community, and then I present various forms of resistance and radicalisation among the Belarusian communities. However, my intention is not to analyse precisely all the episodes and sequences of mechanisms and processes that constitute the trajectory of the contention (cf. McAdam et al., 2001). By examining this particular historical case, I intend to examine how the geocultural mechanism amplified a spiral of repression and radicalisation, creating conditions for the reproduction of the archaic social order.

\footnotetext{
2 The most influential work on the subject remains a classic work The Idea of Nationalism by Hans Kohn, in which he distinguishes two types of nationalism in terms of their geocultural origins. The first one developed in the Western World and was connected with the formation of the national state and the concept of individual liberty. The other one emerged in the backward areas outside the Western World, i.e. in Central and Eastern Europe and in Asia, and "found its first expression in the cultural field" (Kohn, 1944/2005, p. 331).

3 It has been observed that "Kohn's account is highly problematic as 'political' and 'cultural', or 'civic' and 'ethnic', elements are intertwined in almost all actually existing nationalisms, and the 'political', 'civic' nationalisms of the West are not more benign, or liberal, than their allegedly 'cultural', 'ethnic' counterparts" (Özkırımlı, 2010, p. 37).
} 


\section{Geocultural Causal Mechanisms: Coercion and Blocking Change}

The history of the Polish-Lithuanian Commonwealth determines the present-day Polish social reality in many ways (see e.g. Leder, 2014; Smoczyński \& Zarycki, 2017). I identify two mechanisms significant for this part of Europe which are key to the issue of radicalism: coercion and blocking change. Both of them are connected with violence: research shows that violent actions of the state apparatus against social movements trigger radicalisation (della Porta, 2008, 2018), and that violence tends to escalate especially during periods of social transformation (Tilly, 1978).

The role of coercion in the Polish-Lithuanian Commonwealth, or more specifically the relationship between capital and coercion, is highlighted by Charles Tilly, who examines how state forms in Europe have developed (Tilly, 1990). He includes the Commonwealth, much like Russia, Hungary and Prussia, among coercion-intensive areas: regions "of few cities and agricultural predominance, where direct coercion played a major part in production" (Tilly, 1993, p. 142). Here, coercion is understood as a phenomenon devoid of randomness; it "includes all concerted application, threatened or actual, of action that commonly causes loss or damage to the persons or possessions of individuals or groups who are aware of both the action and the potential damage" and "defines a realm of domination" (Tilly, 1990, p. 19).

The merger of two main groups, soldiers and great landlords, who specialised in applying the mechanism of coercion, brought about the rise of a privileged class of nobility (Tilly, 1990). Such a course of events was, of course, a well-known phenomenon also in other parts of Europe, and the state has a monopoly on violence (Weber, 2002). However, some differentiating nuances emerged over time. In the Polish-Lithuanian Commonwealth, unlike in the Western European systems, the Hobbesian state of war of all against all was not brought to an end by the conclusion of a social contract: the order was forcibly imposed by coercive "specialists", and then under duress reproduced by a narrow privileged group. The nobility (szlachta), who regarded the Commonwealth as their private property, managed to arrange the state in such a way that their interests were pursued by all other social classes, except the clergy. In addition to direct coercive measures, they succeeded in concentrating all forms of capital in their hands, including the "metacapital" resulting from the "possession" of the state (Bourdieu, 1998, pp. 81-82), while depriving the other social classes of it. The sense of superiority - implied by the conviction of the members of the Polish nobility about their special advantages, resulting from good birth and the mission of defending Christianity - led to practices which nowadays could be described only as an expression of racism (Davies, 1992, p. 313).

The coercive mechanism clearly manifested itself in the treatment of the peasants, who were relegated to semi-slavery. It seems this was the reason of peasants' passivity. What effectively discouraged open resistance, not to mention radical demands for a change of order, 
were the bestiality with which the disobedience was often punished, as well as the strained living conditions on the verge of survival: hunger, chronic malnutrition, and exploitative work beyond human strength. Referring to the prevalence of discontent among peasants, Tilly points out that collective action requires more than negative emotions, namely "five big components: interest, organization, mobilization, opportunity, and collective action itself" (Tilly, 1978, p. 7). In the former Commonwealth, and especially in the former Grand Duchy of Lithuania, such opportunities occurred during the sluggish modernisation process.

The system of the privileges of the szlachta theoretically fostered social polarisation, dividing society into citizens and subjects, regardless of their financial situation. In fact, the social structure was much more diverse and hierarchical. A significant part of the szlachta did not own land and was a magnate clientele. Such a situation and its consequences were particularly evident especially in the eastern parts of the Commonwealth:

Nowhere more emphatically than in the borderland, Polesian or Ruthenian realms of magnate power, did the fiction of noble democracy appear in its naked truth: in the noble worship of grand lords, magnates, uncrowned kings of the noble mass, kept faithful to their noble idols "by cap and by pap" ("czapka i papka"), [...] in servility towards the great and the mighty and the disdain for equals and the lower. (Obrębski, 2007, p. 37)

Therefore, the dominant-subordinate relationships existed not only between peasants and the szlachta, but also between the representatives of the nobility. While the presence of coercion is clearly evident in the case of peasants due to the use of physical violence, in the case of nobility it is blurred by more subtle forms of influence. Furthermore, the discourse on citizens proclaimed the slogans of freedom, equality and opposition to strong royal power. Yet, although the sanctions for non-compliance were different in both classes, the symbolic exclusion from the ranks of privileged could turn out very severe, resulting in the loss of a comfortable living.

Having said that, I do not see the coercive mechanism through the prism of state violence or similarly to Durkheim, ${ }^{4}$ but as a mechanism where a dominant group imposes obedience to appropriate social reality. Also, it can be seen as a sequence of minor mechanisms, such as mechanisms of depriving a vulnerable group of social agency and disqualifying it from the right to make choices. Furthermore, it triggered many other interrelated cognitive and relational mechanisms with several negative effects.

Firstly, as a result, the sphere of social life is perceived as a zero-sum game: winner-loser (rather than winner-winner) becomes a dominant type of relationship. Thus, the winner is not obliged to share the outcomes of their victory (e.g. power) but "takes it all". In the context of coercion this means that a specific habitus is developed. It makes it possible to adapt to living in an environment where violence is considered a common-sense element of reality. This, in turn, results in applying this type of rules (like compulsion) to every aspect

4 Durkheim strongly insists on the "externality" of the social fact and he views the sense of "coercion" as proof of the externality of social facts (Durkheim, 2000). 
of the social sphere. In other words, such an order is not questioned; instead, every social actor wants to be the winner. Secondly, applying coercion, with the underlying conviction that "the winner takes it all", removed from the public sphere the need of making compromises. Instead, an open disdain, especially to those having lower status, became a kind of social ritual. Thirdly, the lack of the need for compromise eliminated the need for dialogue, which in turn resulted in a lack of ability to hold it. The results of such a situation are seen in the Polish public sphere until this day (see e.g. Kawalec, 2000).

Both mechanisms, of coercion and of blocking change, established a prevalence of cumulative processes over transformational processes in the region (Szücs, 1995). Polish nobility considered the socio-political structure, shaped on second serfdom, ${ }^{5}$ to be perfect, thus any attempts to reform it failed. Official policy and the mechanism of coercion prevented such a society from transformation either into civil or industrial society. As a result, this social structure continued to thrive until the second half of the nineteenth century, and even longer in the Russian partition, despite the formal abolition of serfdom.

However, during the period of partitions, the mechanism of coercion became partially deactivated as the szlachta lost their power and sought the ways to regain it. The same political fight previously carried on against the Polish king was now continued against the Russian tsar in the name of national interests (Tazbir, 1978, p. 70). But Polish landowners - unlike, for instance, English ones (e.g. Moore, 1966, pp. 3-39) - were still generally not in favour of social change, apart from the desire to regain lost privileges.

The combination of the two mechanisms I describe determined in several ways how radicalism was perceived. Firstly, if we ask "radical to what?", we should identify relic social structures as "normal". In other words, what was often mainstream in Western European countries, in the region under scrutiny was seen as radicalism. Secondly, the opposition to radicalism produced not gradualism but a complete lack of change. Endeavours to make even the smallest change were seen as radical, threatening, and were generally considered unacceptable. Thirdly, this dyad shaped an attitude towards disparities and differences whereby they were tolerated as long as they remained in the shadow.

\section{Belarusians in Competition for Their Own Lands}

The Great War and the revolution in Russia radically reshaped the map of Central and Eastern Europe. Before 1914 only Poles sought to construct their own state (Waldenberg, 2000, p. 465). Other nations had seen autonomy within larger state entities as more beneficial. However, after the war many states were created, national by definition and

\footnotetext{
5 Second serfdom (wtórne poddaństwo) is the name given to the intensified form of serfdom in early modern Central and Eastern Europe between the sixteenth and eighteenth centuries, which resulted in the landlords' strengthening and gaining more power over their subordinates (i.e. peasants).
} 
in fact nationalising ones (Brubaker, 1996). ${ }^{6}$ Formation of national states was guided by the right of nations to self-determination, encouraged and popularised by the US President Woodrow Wilson. Nevertheless, in the Second Polish Republic it was not applied equally: Belarusians were a nation deprived of such a right. I claim that this was the result of strong activation of the binary sequence of mechanisms of coercion and of blocking change.

Undoubtedly, compared to other neighbouring nations the nation-building processes in Belarusian society were poorly advanced, among others due to its peasant character. However, after the February Revolution they were dynamised (Lewandowski, 1962; Mironowicz, 2007; cf. Łatyszonek, 1995). This was facilitated by the fluidity of the structures accompanying the revolutionary conditions. Another reason of this acceleration was the war-related migrations, which had an enormous influence on cognitive processes. In the first phase of the war, there was a huge exodus of Belarusian people as a result of resettlement (bezhenstvo) and massive conscription. This turned out to be a formative experience. It was only in the conditions of war and revolution that for the first time thousands of people developed an awareness of their distinctness as Belarusians and began to create a new identity with which they returned to their home villages. Consequently, the returnees brought with them a new way of thinking about the world order and their place in it. Many of them joined the national movement, seeking state sovereignty and at the same time putting forward a programme of social reconstruction.

But despite the accelerated dynamics of the nation-building process, there was not much prospect that Belarusians would succeed in establishing their own state, because "when national, or ethnic, awareness reached there, rival ethnic groups such as the Poles had already staked their claims to certain geographic areas" (Rudling, 2014, p. 29). Polish political milieu was convinced of the historical and moral right of Poles to the entire pre-1772 territories of the Polish-Lithuanian Commonwealth. Insofar the socialists envisaged establishing a federate entity, the nationalists (the Endecja) believed that these lands should be directly incorporated and colonised. The followers of these two rival concepts reckoned neither with political opponents nor with the aspirations of the indigenous people, and only partially took into account the opinion of the Western powers.

Both the objectives and actions of Belarusian activists did not deviate from what at that time and in that region could be called the norm. The Belarusian activists tried to build their own state and armed forces, but this was not possible because of the feeble social power (Elias, 1980), internal structural weakness and unfavourable external conditions. But the overriding factor seems to have been the operation of the geocultural dyad. Poland fought against Soviet Russia for Belarusian lands. Both Poland and Russia,

\footnotetext{
6 The notion of "nationalising state" concerns an ethnically heterogeneous state conceived by its dominant elites as a state of and for one ethnocultural nation. This approach highlights the dynamic nature of the state and its permanent state of "becoming" (vs the static nature of a nation state). Because nationalising state is usually considered "incomplete" or "unrealized", it requires intensive action for and in the name of a "core nation" and justifies abuses against national minorities (Brubaker, 1996).
} 
the two countries with a strong coercive mechanism, neither recognised the existence of a separate Belarusian nation nor allowed the creation of an independent Belarusian state (see more e.g. Gomółka, 1994). Thus, they opposed every effort leading to it. Considering the claims of the neighbours, who were willing to enforce them with violence, the Belarusian People's Republic, established in March 1918, was "a stillborn child" (Lindner, 1999, p. 41).

\section{Coercion and Polish Nation State Building}

While during the war only a small group of politically engaged Belarusians could have been characterised as radical, with the establishing of Polish rule in the Belarusian lands in 1919 radicalisation of both beliefs and means of action proliferated also among members of the conservative peasant community. The change that was beneficial for Poles was made and supported by coercion. In the seized territories, even before the borders were established, persecutions and destruction of Belarusian cultural and human resources began. Belarusian schools were liquidated, Orthodox churches were appropriated, newspapers were closed down. People of Belarusian origin were dismissed from public institutions and enterprises. The indigenous population, on the brink of survival, was robbed of everything. During military requisitions, those who lived in the dugouts were divested even of straw mattresses; also pieces of fabric and leather leftovers, used to produce shoes, were confiscated (Gierowska-Kałłaur, 2011, pp. 774-775; Łuckiewicz, 1920, p. 8). People caught on the roads in severe winter conditions had their sheepskin coats and shoes taken and were turned back to their homes barefoot (Łuckiewicz, 1920, p. 7).

Terror was unleashed especially in the Grodno region, where various Belarusian civic and national projects were carried out, such as the formation of the Belarusian army, the building of local administrative structures, the development of cultural institutions. This mechanism of coercion was applied at closely interrelated levels: micro (local Polish landowners taking revenge on Belarusian peasants by hiring Polish warlords to terrorise them), meso (local administration, controlled by Polish landowners, representing their interests and terrorising Belarusian people) and macro (the government in Warsaw accepting and financing the local practices). Those whom the new Polish authorities suspected of disobedience were arrested, heavily beaten and tortured, which often resulted in permanent disability, and the villages they came from were burnt (Łuckiewicz, 1920, pp. 8-11).

In addition to persecution and intimidation, measures to "eliminate the real or potential threat from the subordinate social category" (Nijakowski, 2013, p. 16) were taken not only against the leaders of socio-political life but also against those who could become ones. That is to say, against those who were literate and claimed to be Belarusian. During the "'cleansing' of the Belarusian country of dangerous elements" (Łuckiewicz, 1920, p. 16), those who were not shot on the spot or tortured to death were put into prisons or concentration 
camps, where they died of typhoid or from where they were sent to the army of Denikin (Łuckiewicz, 1920, p. 16).

In this way, already in the Spring of 1919, the majority of teachers and animators of Belarusian cultural life from the Grodno region were imprisoned in the concentration camps in Białystok and Kraków (Mironowicz, 1999, p. 879). Half a year later, as Mieczysław Niedziałkowski reported in his parliamentary proposal, more than 20,000 civilians from areas under the Civil Administration of the Eastern Lands (Zarząd Cywilny Ziem Wschodnich) ${ }^{7}$ were imprisoned or interned (Lewandowski, 1962, p. 218).

However, the basis of the accusations was not the activities towards the establishment of a Belarusian state, or ones aiming to make the life of the Belarusian people better, but communism. Anyone whose loyalty to the Polish authorities raised any doubts was called "Bolshevik" or "communist".

It was with Bolshevik Russia that Poland signed a peace treaty in Riga in March 1921, thus splitting the Belarusian lands in half. Hence, the decision on the partition of Belarus was made without the Belarusians. The demands of the Belarusian community were not taken into account not because of their radicalism, but because they did not have to be taken into account: since the Belarusian claims were treated as irrelevant, there were no political consequences facing those who opposed them. Even such a discriminated social group as Jews had more influential political representatives: the pogroms, publicised by the diaspora, reached public opinion and they became the subject of an international investigation. But no one interceded for the Belarusians: in a cultural area where problems were resolved through various forms of coercion, they were too weak to care what was happening to them.

As a result of the Treaty of Riga, the Belarusians became a national minority in the Second Polish Republic. They were protected by law, including the Minority Treaty and the March Constitution; the latter guaranteed every citizen "the right to preserve his nationality and cultivate his own speech and national characteristics" (Article 109). However, the coercive mechanism was not bound by law.

\section{Belarusians on a Radical Path}

Although Poles perceived Belarusians in the reductionist perspective as "ignorant masses", in fact at the time in the Belarusian community there occurred complex and dynamic processes of nation-building, understood as cultural, social and political emancipation. Simultaneously, the mechanisms leading to breakdown of the traditional commu-

7 The Civil Administration of the Eastern Lands was responsible for the Polish administration of the eastern lands of the Second Polish Republic, i.e. Lithuania, Belarus and Volhynia (the former Grand Duchy of Lithuania) in 1919-1920. These territories were occupied by the Polish Army, but not incorporated into Poland. 
nity were at work there. One of them was the loss of trust in the power of state, which attacked its citizens instead of protecting them. Consequently, some of the members of the traditional community were driven towards modern forms of social life. Belarusians entered an intensive phase of national agitation (Hroch, 2003), supported by external events and processes. Here, revolutionary conditions played a pivotal role. They helped to create the brokerage mechanisms (McAdam et al., 2001) and enabled connections between national activists and the peasant community. Furthermore, the Polish state apparatus paradoxically facilitated these processes by making cultural distinctness visible. It seems that the politically engaged Polish milieus understood this very well and they tried to prevent the development of Belarusian education and culture.

Some Belarusian politicians believed in declarations made by Józef Piłsudski and were supported by Polish authorities in their activities against Soviet Russia. Nevertheless, the majority of Belarusian politicians had already developed a hostile rather than reluctant attitude to such cooperation. Supported mostly by Lithuania, where the Belarusian government in exile was based, but also by the Soviets, they were preparing for the anti-Polish uprising and for the organisation of a guerrilla movement. A few months earlier, the Belarusian peasantry had risen against the Bolsheviks in the eastern part of the country (Łatyszonek, 1995, p. 138). This illustrates the lack of continuity when it comes to such activities: most of them were ad hoc and not planned.

Western Belarus was not an area of guerrilla warfare or a national uprising but it was split into local zones of passive or active resistance, containing elements of peasant wars and social banditry and rejecting poverty and submission (Hobsbawm, 1959, pp. 13-29). The leaders of the movement intended to create an underground organisation that could be activated in case of a Polish-Lithuanian or Polish-Soviet war, so most of the peasants who went underground remained would-be partisans. The others, at the urging of local leaders, put themselves up for diversionary and sabotage campaigns and raided objects associated with the Polish rule, such as police stations, warehouses, shops, foresters' lodges, manor houses (dwory). The authorities regarded such actions as ordinary criminal acts (Łatyszonek \& Mironowicz, 2002, p. 173).

The radicalism of Belarusian actions triggered a wave of repression by the authorities. After the end of the warfare in 1920, the Polish government considered that the primary way to ensure security was to fight against the activity of subversive organisations (Śleszyński, 2005, p. 22). The implementation of summary executions (sądy doraźne) resulted in the rule whereby the members of the guerilla who were caught were executed on the spot. Moreover, during joint military and police operations ordinary Belarusian villages were surrounded to conduct searches (Śleszyński, 2005, p. 31) and make mass arrests.

Although the guerrillas were not very well versed in the political situation (Mironowicz, 2007), it cannot be said that they were unconscious tools in the hands of foreign, especially Soviet, decision-makers; rather, they used their resources to achieve their own objectives. It seems that the radicalism of the measures was both reactive: it was 
a "response to humiliations" (Śleszyński, 2008, p. 185), and active: it was accompanied by expectations of a new order in which "everything will be for Belarusians" (after: Tokts', 2007, p. 209).

In the described actions, various types of radicalism overlapped. The first, social, was based on the demands for land reform, necessary to enable the economic development of the whole region. Because the authorities viewed these demands as a threat to the state and the interests of Polish landowners, they did not intend to yield, regardless of how the land reform issue (kwestia agrarna) would be solved. In this context, raising the issue was radical as such. Initially, Belarusian peasants, as "property fanatics" (after: Lewandowski, 1962, p. 210), rejected communist ideology, with the Bolshevik plan of taking away the landowners' land. Yet, the repressive policy of the Polish state significantly contributed to their radicalisation (Gomółka, 1992, p. 44; Lewandowski, 1962, pp. 231-236), which manifested as escalated claims for land without redemption. In contrast, it is worth noting that Polish military settlers usually obtained land free of charge (Chojnowski, 1979, p. 46).

The second type of radicalism can be called the civic-national type. The demands for the reunification of Belarusian territories and for their own state, in which Belarusians would become hosts rather than second-class citizens, were in accordance with the principle of national sovereignty and civil rights, popular in Europe at the time. From the Western European perspective, then, they were hardly radical. However, after the partition of Belarusian lands between Poland and Russia, promoting the idea of an independent Belarusian state was considered to be subversive activity in both countries.

The third type of radicalism can be described as a radicalism of tradition (Calhoun, 2012, pp.55-89). In general, most of the partisans came from the rural communities where the traditional way of life and thinking continued to prevail. Since, within the framework imposed by the Polish authorities, the Belarusian peasant was again reduced to the subject of their Polish master, with quasi-feudal burdens, their possible involvement in folk tradition turned into a radical threat to the new system. In line with the observation that "communities in which interpersonal relations are densely knit, many-faceted, and organized in harmony with traditional values can be potent informal organizations on which to base sustained insurgency" (Calhoun, 2012, p. 95), loyalty networks within the traditional peasant community were employed as the basis for the organisation of a guerrilla movement. Moreover, although the peasant community was exhausted by war and first of all endeavoured to ensure their subsistence, the scale of repression was perceived as a threat both to physical and cultural survival. The persecutions carried by Poles were so severe that, despite the exhaustion, in order to survive the Belarusian people had to unite, organise and fight back. Even if all they wanted was peace, there was no alternative but to fight. Therefore, the very existence of the Belarusian traditional community, caring for its own cultural tradition, turned out to be radical. 


\section{Peaceful Radicalism of the Mass Social Movement}

One of the reasons why the guerrilla movement ceased was the fact that in 1923 the Western powers recognised Poland's eastern border, drawn by the Treaty in Riga. The minimal possibilities for legal action were reflected by the radicalism of the measures taken (i.e. guerrilla). The legal possibilities were actually only theoretical. Pro-Polish activists who wanted to use the democratic mechanisms in the struggle for cultural autonomy and who got into parliament realised this painfully. The deputies, gathered around Bronisław Taraszkiewicz $^{8}$ and so far loyal to Poland, confronted with the impossibility of political dialogue and deprived of influence on reality, made a radical turn towards communist ideology and started to cooperate with the Soviet Union (Bergman, 1977). The Hromada, which they established in 1925, did not find many followers for several months. This changed only when another component of Tilly's "big five" came into play: the opportunity, stemming from "the inertia of the local apparatus of power after the May coup, waiting for instructions, afraid of taking actions contrary to the intentions of the new ruling camp" (Łatyszonek \& Mironowicz, 2002, p. 177). Thus, the Hromada transformed into a mass peaceful social movement.

The radicalism of measures was replaced to some extent by radical beliefs: to some extent, because similar beliefs had already coexisted with radical methods. Moreover, it seems that in the perception of Polish political circles the mass mobilisation was a more unacceptable phenomenon than Hromada's demands. In the existing social order there was no place for something like a mass peasant movement, especially a Belarusian one. The very fact of the transformation not only of individuals but also of the entire subordinated social class into an agent was disturbing and threatening. In addition, the risk posed by Hromada was all the greater considering that it united almost all Belarusian milieus as well as "the Belarusian political front by suppressing an organisational pluralism among the opposition" (Fedorowycz, 2020, p. 2).

The mechanisms of coercion and of blocking change were so strong that Belarusians were pacified regardless of the methods they undertook to improve their fate. Thus, the Hromada was dealt with as usual: by repressions. Searches and arrests followed, and then Hromada activists, including illegally jailed deputies, were brought to trial. A few weeks later the organisation was banned. Belarusians lost almost all their representatives

8 Bronisław Taraszkiewicz (1892-1938) was a Belarusian activist, political leader, philologist and teacher. A graduate of Petersburg University, he was the author of the first standard grammar of the modern Belarusian language, Belaruskaia hramatyka dlia shkol [Belarusian Grammar for Schools], the translator of Pan Tadeusz into Belarusian, and a deputy to the Polish Parliament in 1922-1927. At first he was positive towards Polish authorities, but his subsequent disenchantment in their policy led him to become an activist of the Belarusian opposition in the Polish Sejm. He became a member of the underground Communist Party of Western Belarus (Komunistyczna Partia Zachodniej Białorusi) and the leader of the Hromada. Imprisoned in Poland, he was exchanged for another prisoner and from then lived in Soviet Belarus. He was executed in 1938 during the Great Purge, and posthumously rehabilitated in 1957. 
in parliament, and the national movement survived only in a rudimentary form. Belarusian radicalism was considered to have been effectively eradicated. The coercive mechanism only preserved this state of affairs; it can be said that "tyrannical peace" (Davenport, 2007b) was established.

\section{Conclusions}

The reasons for the radicalisation of Belarusians in the second and third decades of the twentieth century were complex. We cannot claim with certainty when this process started, not only because it began simultaneously in many places and at different times. As discussed above, it is also impossible to give an exact definition of one, coherent radicalism. Belarusian society was rapidly and profoundly transformed during the Great War, but to call this "radicalisation" does not seem entirely justified, as it was rather a process of adaptation. Belarusians were not at the vanguard of change: they rather adjusted to rapidly changing conditions of the times than contested them. In the case under consideration, the "mainstream" was the order established by the successive groups in power in the Belarusian lands: first Poles, then Soviets, and then Poles again, since it was them who determined what should be considered "normal" and what - "radical". The radicalisation of Belarusians partly resulted from shifting the context. It was switched by Poles by imposing their own standards of what was "normal" on the Belarusian territory they occupied. Above all, radicalism was a reaction to the terror and brutal violence that the officers of the Polish state apparatus used against civilians, not involved in either military or political activities. It was the terror and brutal violence pursued in 1919 and 1920 that seem to be crucial for Belarusian radicalism, because it appeared as a response to the actions of Poles.

Yet, there are some difficulties to explain these activities. With all its violent instrumentation, coercion is well known in cultures all around the world, as is the fact that "when challenges to the status quo take place, authorities generally employ some form of repressive action to counter or eliminate the behavioral threat" (Davenport, 2007a, p. 8). Initially, Belarusians did not pose a threat to the Polish state, and ensuring public security was not an issue, unlike in the subsequent period, when Belarusians started the fight for their rights (cf. Cichoracki, 2012; Śleszyński, 2007). Many reports of Polish activists (Gierowska-Kałłaur, 2011) include the motif of powerlessness against the scale and cruelty of violence used by the Polish military and administration against Belarusian people. The phenomenon of large-scale violence was portrayed as irrational and unmanageable. Despite widespread criticism on the part of left-wing political parties such as the Polish Socialist Party (more: Gomółka, 1992, pp. 36-57) and the obvious harm of such a strategy for Polish statehood (cf. Srokowski, 1924), successive groups in power continued using political violence (cf. Chojnowski, 1979; Mironowicz, 2007; Śleszyński, 2007). Such 
persistent use of a self-damaging strategy could be a signal of the presence of latent or not entirely overt and conscious factors.

This situation can be explained by the geocultural causal mechanisms. Although the Belarusians were not a threat to the Polish state, they were a potential threat to its vision. The mechanism of blocking change required that the modern Polish State be reactivated as a close replica of the Polish-Lithuanian Commonwealth. Because Belarusian peasants were the lowest-situated social group, when thinking in the then still used categories of feudal hierarchy the question of their agency was not raised. But the Russian Revolution and the social changes taking place in the region under scrutiny were a major impediment on the way to restoring the ancien régime. The coercive mechanism was activated by the fear that Belarusian people would participate in the transformation, which in result led to the radicalisation of Belarusians.

A complete return to the past turned out to be unrealistic, but the two mechanisms did not cease to function: having successfully enforced the order, they served to preserve it. Thus, causal mechanisms not only contributed to the beginning of radicalisation, but also affected its trajectory. Although "the Polish government managed to suppress the activity of the armed groups, to enforce the peasants to submission and to establish a relative order, it was an administration based on violence and not a solution to the problem of the Eastern Borderlands" (Tomaszewski, 1988, p. 110). This issue could not be resolved as long as geocultural mechanisms dominated and precluded change. Therefore, the political opportunities that Hromada counted on and made use of turned out to be deceptive (cf. della Porta, 2008); the causes of oppression went beyond ultranationalism and thus the removal of the National Democracy from power did not eliminate them.

The radical response of Belarusians was not unique: in many historical cases, radicalisation spread under the influence of political violence and the sense of injustice experienced in everyday life (della Porta, 2018, p. 464). It has been often observed that the more the repression is perceived as indiscriminate, the more solidarity with militant groups increases (della Porta, 2018, pp. 464-465). In the radicalism of Belarusians, one can see a rational reaction to systemic solutions that were harmful and enforced by violence. The constant exposure to violence and the disregard for basic needs on the part of Polish authorities transformed Belarusian identities: Belarusians came to see the only chance of satisfying their needs in the establishment of their own state. Thus, the activation of the two mechanisms, of coercion and of blocking change, in the realities of the nationalising state resulted in unintended and unwanted consequences, such as the social-national mobilisation and radicalisation of the indigenous people. 


\section{References}

Bergman, A. (1977). Rzecz o Bronisławie Taraszkiewiczu. Książka i Wiedza.

Bourdieu, P. (1998). Practical reason: On the theory of action. Stanford University Press.

Brubaker, R. (1996). Nationalism reframed: Nationhood and the national question in the new Europe. Cambridge University Press. https://doi.org/10.1017/CBO9780511558764

Calhoun, C. (2012). The roots of radicalism. University of Chicago Press. https://doi.org /10.7208/chicago/9780226090870.001.0001

Chojnowski, A. (1979). Koncepcje polityki narodowościowej rządów polskich w latach 1921-1939. Ossolineum.

Cichoracki, P. (2012). Stołpce-Łowcza-Leśna 1924: Il Rzeczpospolita wobec najpoważniejszych incydentów zbrojnych w województwach północno-wschodnich. Wydawnictwo LTW.

Davenport, C. (2007a). State repression and political order. Annual Review of Political Science, 10(1), 1-23. https://doi.org/10.1146/annurev.polisci.10.101405.143216

Davenport, C. (2007b). State repression and the tyrannical peace. Journal of Peace Research, 44(4), 485-504. https://doi.org/10.1177/0022343307078940

Davies, N. (1992). Boże igrzysko: Historia Polski (E. Tabakowska, Trans.; Vol. 1). Znak.

della Porta, D. (2008). Research on social movements and political violence. Qualitative Sociology, 31(3), 221-230. https://doi.org/10.1007/s11133-008-9109-x

della Porta, D. (2018). Radicalization: A relational perspective. Annual Review of Political Science, 21(1), 461-474. https://doi.org/10.1146/annurev-polisci-042716-102314

Durkheim, É. (2000). Zasady metody socjologicznej (J. Szacki, Trans.; 2nd ed.). Wydawnictwo Naukowe PWN.

Elias, N. (1980). Przemiany obyczajów w cywilizacji Zachodu (T. Zabłudowski, Trans.). Państwowy Instytut Wydawniczy.

Fedorowycz, D. (2020). Beyond ideology: Reassessing the threat of Belarusian opposition in interwar Poland. Nationalities Papers, 2020, 1-18. https://doi.org/10.1017/nps.2020.44 Gierowska-Kałłaur, J. (Ed.). (2011). Raporty Straży Kresowej 1919-1920. Wydział Dziennikarstwa i Nauk Politycznych, Uniwersytet Warszawski; ASPRA-JR; Akademia Humanistyczna im. Aleksandra Gieysztora.

Gomółka, K. (1992). Białorusini w II Rzeczypospolitej. Wydawnictwo Politechniki Gdańskiej. Gomółka, K. (1994). Między Polska a Rosją: Białoruś w koncepcjach polskich ugrupowań politycznych 1918-1922. Warszawska Oficyna Wydawnicza.

Hobsbawm, E. (1959). Primitive rebels. Manchester University Press.

Hroch, M. (2003). Małe narody Europy: Perspektywa historyczna (G. Pańko, Trans.). Ossolineum. Kawalec, K. (2000). Spadkobiercy niepokornych: Dzieje polskiej myśli politycznej 1918-1939. Ossolineum.

Kohn, H. (2005). The idea of nationalism: A study in its origins and background. Transaction Publishers. (Original work published 1944).

Łatyszonek, O. (1995). Białoruskie formacje wojskowe 1917-1923. Białoruskie Towarzystwo Historyczne. 
Łatyszonek, O., \& Mironowicz, E. (2002). Historia Białorusi: Od połowy XVIII do końca XX wieku. Związek Białoruski w Rzeczypospolitej Polskiej; Katedra Kultury Białoruskiej Uniwersytetu w Białymstoku.

Leder, A. (2014). Prześniona rewolucja: Ćwiczenie z logiki historycznej. Krytyka Polityczna. Lewandowski, J. (1962). Federalizm. Państwowe Wydawnictwo Naukowe.

Lindner, R. (1999). Historiker und Herrschaft: Nationsbildung und Geschichtspolitik in Weißrußland im 19. und 20. Jahrhundert. Oldenbourg.

Łuckiewicz, A. (1920). Polska okupacja na Białorusi. [n.p.].

Mackiewicz, J. 1994. Lewa wolna. Kontra

Malthaner, S. (2017). Radicalization: The evolution of an analytical paradigm. European Journal of Sociology, 58(3), 369-401. https://doi.org/10.1017/S0003975617000182

McAdam, D., Tarrow, S., \& Tilly, C. (2001). Dynamics of contention. Cambridge University Press. https://doi.org/10.1017/CBO9780511805431

Mironowicz, E. (1999). Antypolska konspiracja białoruska w latach 1919-1925. In K. Jasiewicz (Ed.), Europa nieprowincjonalna (pp. 877-884). Instytut Studiów Politycznych PAN; Oficyna Wydawnicza Rytm.

Mironowicz, E. (2007). Białorusini i Ukraińcy w polityce obozu piłsudczykowskiego. Trans Humana. Moore, B., Jr. (1966). Social origins of dictatorship and democracy. Beacon Press.

Nijakowski, L. M. (2013). Rozkosz zemsty: Socjologia historyczna mobilizacji ludobójczej. Wydawnictwo Naukowe Scholar.

Obrębski, J. (2007). Polesie. Oficyna Naukowa.

Özkırımlı, U. (2010). Theories of nationalism: A critical introduction. Palgrave Macmillan.

Rudling, P. A. (2014). The rise and fall of Belarusian nationalism, 1906-1931. University of Pittsburgh Press. https://doi.org/10.2307/j.ctt1287p7r

Sedgwick, M. (2010). The concept of radicalization as a source of confusion. Terrorism and Political Violence, 22(4), 479-494. https://doi.org/10.1080/09546553.2010.491009 Śleszyński, W. (Ed.). (2005). Walka instytucji państwowych z białoruską działalnością dywersyjna 1920-1925. Wydawnictwo Prymat.

Śleszyński, W. (2007). Bezpieczeństwo wewnętrzne w polityce państwa polskiego na ziemiach północno-wschodnich II Rzeczypospolitej. Instytut Studiów Politycznych PAN; Instytut Historii Uniwersytetu w Białymstoku; Oficyna Wydawnicza Rytm.

Śleszyński, W. (2008). Białoruska działalność dywersyjna w pierwszej połowie lat dwudziestych i formowanie się Białoruskiej Włościańsko-Robotniczej Hromady. Białoruskie Zeszyty Historyczne, 29, 183-191.

Smoczyński, R., \& Zarycki, T. (2017). Totem inteligencki. Wydawnictwo Naukowe Scholar. Srokowski, K. (1924). Sprawa narodowościowa na kresach wschodnich. Gebethner i Wolff. Szűcs, J. (1995). Trzy Europy (J. M. Kłoczowski, Trans.). Instytut Europy Środkowo-Wschodniej. Tazbir, J. (1978). Kultura szlachecka w Polsce: Rozkwit, upadek, relikty. Wiedza Powszechna. Tilly, C. (1978). From mobilization to revolution. Addison-Wesley.

Tilly, C. (1990). Coercion, capital and European states: AD 990-1990. Basil Blackwell. 
Tilly, C. (1993). The long run of European state formation. In W. P. Blockmans \& J.-P. Genet (Eds.), Visions sur le développement des États européens (pp. 137-150). École française de Rome. https://www.persee.fr/doc/efr_0000-0000_1993_act_171_1_3036

Tokts', S. (2007). Belaruskaia vioska ŭ épokhu z'menaŭ: Druhaia palova XIX - pershaia tratsina XX st. Tëkhnaliohiia.

Tomaszewski, J. (1988). Kresy Wschodnie w polskiej myśli politycznej XIX i XX w. In W. Wrzesiński (Ed.), Polska myśl polityczna XIX i XX wieku: Vol. 6. Między Polska etniczna a historyczna (pp. 97-118). Ossolineum.

Tormey, S. (2008). Radicalism. In W. A. Darity (Ed.), International encyclopedia of the social sciences (2nd ed., Vol. 7, pp. 48-51). Macmillan Reference.

Waldenberg, M. (2000). Narody zależne i mniejszości narodowe w Europie Środkowo-Wschodniej. Wydawnictwo Naukowe PWN.

Weber, M. (2002). Gospodarka i społeczeństwo: Zarys socjologii rozumiejącej (D. Lachowska, Trans.). Wydawnictwo Naukowe PWN.

\title{
O tym, jak Polacy radykalizowali Białorusinów i o mechanizmie przymusu
}

\begin{abstract}
Abstrakt
Wielka przebudowa Europy Środkowo-Wschodniej po pierwszej wojnie światowej polegała w dużej mierze na budowaniu państw narodowych w miejsce wielonarodowych imperiów; aczkolwiek obejmowała także przekształcenia społeczne. Wybiórczość zmian przeprowadzanych na silnie zróżnicowanych etnicznie, a przy tym spolaryzowanych społecznie, obszarach byłej Rzeczypospolitej Obojga Narodów przyczyniała się do wystąpień miejscowej ludności. Ich radykalizm był często odpowiedzią na nowy ład, będący próbą reprodukcji feudalnego porządku w realiach państwa narodowego. W artykule odtwarzam trajektorię radykalizacji, jaką przeszli w nierównej walce o swoje prawa Białorusini. Próbuję wyjaśnić radykalizm społeczności białoruskiej poprzez uwarunkowania geokulturowe, które traktuję jako mechanizmy przyczynowe, powtarzające się w różnych kontekstach historycznych. Identyfikuję dwa takie mechanizmy: przymusu i blokowania zmiany. Prezentuję, w jaki sposób radykalizm warunkowany był działaniem tej binarnej sekwencji.
\end{abstract}

Słowa kluczowe: Białorusini; Druga Rzeczpospolita; radykalizacja; przymus; represje

\section{Citation}

Kurza, K. (2021). How Poles radicalised Belarusians: On the mechanism of coercion. Sprawy Narodowościowe: Seria nowa, 2021(53), Article 2482. https://doi.org/10.11649/sn.2482 